\title{
The role of seaports in regional development in the East Coast of Peninsular Malaysia: An evaluation through an exploratory factor analysis
}

\begin{tabular}{|c|c|}
\hline $\begin{array}{l}\text { Authors: } \\
\text { Raja Somu }{ }^{1} \\
\text { Jagan Jeevan } \\
\text { Nurul H. Moh } \\
\text { Mohamad R. } \\
\text { Kasypi Mokht } \\
\text { Abdul H. Ngar }\end{array}$ & $\begin{array}{l}\text { (D) } \\
\text { Salleh }{ }^{1} \text { (D) } \\
\text { Dthman }^{1} \text { (D) } \\
\text { a }^{1} \text { (D) } \\
2^{2} \text { (D) }\end{array}$ \\
\hline $\begin{array}{l}\text { Affiliations: } \\
{ }^{1} \text { Department } \\
\text { Management } \\
\text { Maritime Stuc } \\
\text { Malaysia Tere } \\
\text { Nerus, Malays }\end{array}$ & $\begin{array}{l}\text { f Maritime } \\
\text { Faculty of } \\
\text { lies, University } \\
\text { gganu, Kuala } \\
\text { ia }\end{array}$ \\
\hline $\begin{array}{l}{ }^{2} \text { Department } \\
\text { Economics an } \\
\text { Development } \\
\text { Business, Eco } \\
\text { Social Develo } \\
\text { University Ma } \\
\text { Terengganu, K } \\
\text { Malaysia }\end{array}$ & $\begin{array}{l}\text { f Business, } \\
\text { d Social } \\
\text { Faculty of } \\
\text { omics and } \\
\text { ment, } \\
\text { laysia } \\
\text { uala Nerus, }\end{array}$ \\
\hline $\begin{array}{l}\text { Correspondin } \\
\text { Jagan Jeevan, } \\
\text { jagan@umt.e }\end{array}$ & $\begin{array}{l}\text { g author: } \\
\text { du.my }\end{array}$ \\
\hline $\begin{array}{l}\text { Dates: } \\
\text { Received: } 02 \\
\text { Accepted: } 26 \\
\text { Published: } 31\end{array}$ & $\begin{array}{l}\text { une } 2021 \\
\text { Oct. } 2021 \\
\text { Jan. } 2022\end{array}$ \\
\hline $\begin{array}{l}\text { How to cite th } \\
\text { Somu, R., Jee } \\
\text { Salleh, N.H., } \\
\text { Mokhtar, K. \& } \\
2022, \text { 'The rol } \\
\text { in regional de } \\
\text { the East Coas } \\
\text { Malaysia: An } \\
\text { through an ex } \\
\text { factor analysi } \\
\text { Transport ano } \\
\text { Management } \\
\text { https://doi.or } \\
\text { jtscm.v16i0.6 }\end{array}$ & $\begin{array}{l}\text { is article: } \\
\text { an, J., Mohd } \\
\text { thman, M.R., } \\
\text { Ngah, A.H., } \\
\text { e of seaports } \\
\text { velopment in } \\
\text { of Peninsular } \\
\text { valuation } \\
\text { ploratory } \\
\text {, Journal of } \\
\text { Supply Chain } \\
16(0), \text { a617. } \\
\text { /10.4102/ } \\
7\end{array}$ \\
\hline $\begin{array}{l}\text { Copyright: } \\
\text { (C) 2022. The } \\
\text { Licensee: AOS } \\
\text { is licensed un } \\
\text { Creative Com } \\
\text { Attribution Lic }\end{array}$ & $\begin{array}{l}\text { uthors. } \\
\text { IS. This work } \\
\text { ler the } \\
\text { nons } \\
\text { ense. }\end{array}$ \\
\hline Read online: & \\
\hline 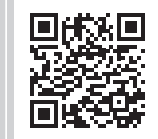 & $\begin{array}{l}\text { Scan this QR } \\
\text { code with your } \\
\text { smart phone or } \\
\text { mobile device } \\
\text { to read online. }\end{array}$ \\
\hline
\end{tabular}

Background: This paper explores the concept of regional development by utilising the benefits generated by seaports. The east coast of peninsular Malaysia is the focus region of this research because of the imbalance of regional development compared to the west coast. Integration amongst multimodal transportation, freight corridors, seaports and transport facilities has remained underutilised as a result of the lack of policy integrating seaports as the main component in regional development.

Objectives: Further, the preparation of seaports in east coast peninsular Malaysia to meet the requirements of the international agenda especially the Belt and Road Initiative (BRI) has become the main motivation for this study.

Method: The paper explores the main factors in seaport systems that influence regional development in the east coast region and examines the implications of seaport systems on regional development and vice versa, as well as proposes development strategies for the growth of seaports in this particular region. Exploratory factor analysis (EFA) has been employed to achieve the proposed objectives in this paper.

Results: The outcome shows two main impacts seaports have on regional development, namely geo-economics development and social development.

Conclusion: Furthermore, the progress made in the regional development might improve the dynamism of seaports and could transform the seaport as a maritime logistics hub in this region. Finally, maritime sustainable strategy, seaport integration strategy and administrative strategy can be implemented in seaports at east coast region for the continual development.

Keywords: seaport; regional development; east coast of peninsular Malaysia; exploratory factor analysis; quantitative.

\section{Introduction}

Seaports are major nodes that boost national trades and spark the growth of the nation. Malaysia's geographic location between the South China Sea and the Malacca Straits justifies the importance of maritime activities in this region. The South China Sea and the Malacca Straits are the world's busiest shipping lanes. This is because Strait of Malacca is the shortest shipping route between the Far East and the Indian Ocean. Ships have passed through it for centuries, and trading posts sprang up at an early stage, growing into centres of education, science and art at the same time. Apart from that, Malaysia's seven major seaports, five mainly used for containers and two for oil and gas, contribute enormously to its development and economic growth (Chen, Jeevan \& Cahoon 2016). Almost 75\% of the country's land is exposed to maritime water (Jeevan et al. 2021a). This grants Malaysia the advantage to be a strategic country that is readily available for the development of the maritime industry (Chen et al. 2016).

The location of peninsular Malaysia in between the South China Sea and Malacca Straits justifies the importance of maritime activities in this region. Both of these waters carried almost $30 \%$ of global trades, which indicates the importance of seaports and maritime trade along this region (Jeevan et al. 2020). Moreover, when it comes to boosting the local economy, Malaysia's maritime industries are critical players. Malaysia's oceans serve as host shipping routes, providing a platform for potential economic activities such as transportation, tourism, shipbuilding and ship repair, as well as port services. This sector accounts for $40 \%$ of Malaysia's gross domestic product (GDP), with oil and gas accounting for $15 \%$ of total output and fisheries accounting for $9.4 \%$ of total output (Menhat et al. 2021). 
Malaysia's east coast has lagged far behind its western counterpart in terms of regional development. Malaysia's prominent container terminals, such as Port Klang and Port Tanjung Pelepas, are ranked amongst the top 20 ports in terms of volume (Salleh et al. 2021). It can be clearly seen from Figure 1 that four out of the five major container seaports of Malaysia are located close to Malacca straits, the west coast of peninsular Malaysia. These disproportionately located container seaports in Malaysia can be viewed as a source of imbalanced development between the east and west coast of the country (Latip et al. 2019).

As a result, the regional development on the east coast is far behind in the context of infrastructure quality, community services, production volume, employability, number of jobs and quality of life. This is demonstrated by the concentration of intra-state rail freight links and key manufacturing centres on the west coast of Peninsular Malaysia as opposed to the east coast (Jeevan et al. 2020). The equality in the regional development in peninsular Malaysia will ensure stability in economic growth by executing trading activities equally throughout the region (Jeevan et al. 2021b). As seaports in this region are considered as nexus for international trade, these nodes have gained sufficient support from the both parties including central and local government as well as private sectors (Salleh et al. 2021a). For effective and efficient investment, operation and administration, the majority of seaports in the nation follow the Public Private Partnership (PPP) strategy (Jeevan, Chen \& Cahoon 2019; Jeevan et al. 2021). The public sector, particularly the ports authority, supplies land and manages administrative responsibilities under this model (Jeevan et al. 2021). Whilst the private sector is in charge of ports operations and is accountable for increasing the competitiveness. Port Klang in Malaysia is an excellent example of a public body (seaport authority) backed by two private operators in the same location. Apart from that, Port Klang is Malaysia's predominant seaport and serves as the country's primary seaport. The Port of Klang Authority is in charge of two port operators, namely the north port and the west port. Port Klang, originally known as Port Swettenham, renamed in July 1972, is the country's busiest port and the largest in Southeast Asia. The Port is located about $6 \mathrm{~km}$ southwest of the town of Klang and $38 \mathrm{~km}$ southwest of the capital city of Kuala Lumpur in Malaysia. In addition to dedicated multipurpose port facilities and services, Northport (Malaysia) Bhd owns and operates Northport (Malaysia). Westport is managed by Westports Malaysia Sdn Bhd, which is a Malaysian corporation. The Port Klang Cruise Centre, which serves as a passenger port in addition to the cargo terminals of Westport, is also located nearby (Jeevan et al. 2015; Othman 2020; Salleh et al. 2021).

This research aligns with the Malaysian Logistics and Trade Facilitation Master Plan, which provides strategies and guidelines to enhance the competitiveness of Malaysia's transport and trade facilitation mechanisms (EPU 2015). This research aims to examine the implications of seaport systems on regional development in the east coast of peninsular Malaysia and vice versa. It also proposes development strategies for the growth of seaports in this particular region. It may prove useful to policymakers in focusing on regional development derived from maritime activities, increasing equality in regional development in Peninsular Malaysia and prioritising key components of the seaport system that are critical for regional development.

\section{The concept of regional development}

Several researchers and affiliated organisations have provided different definitions of regional development. According to

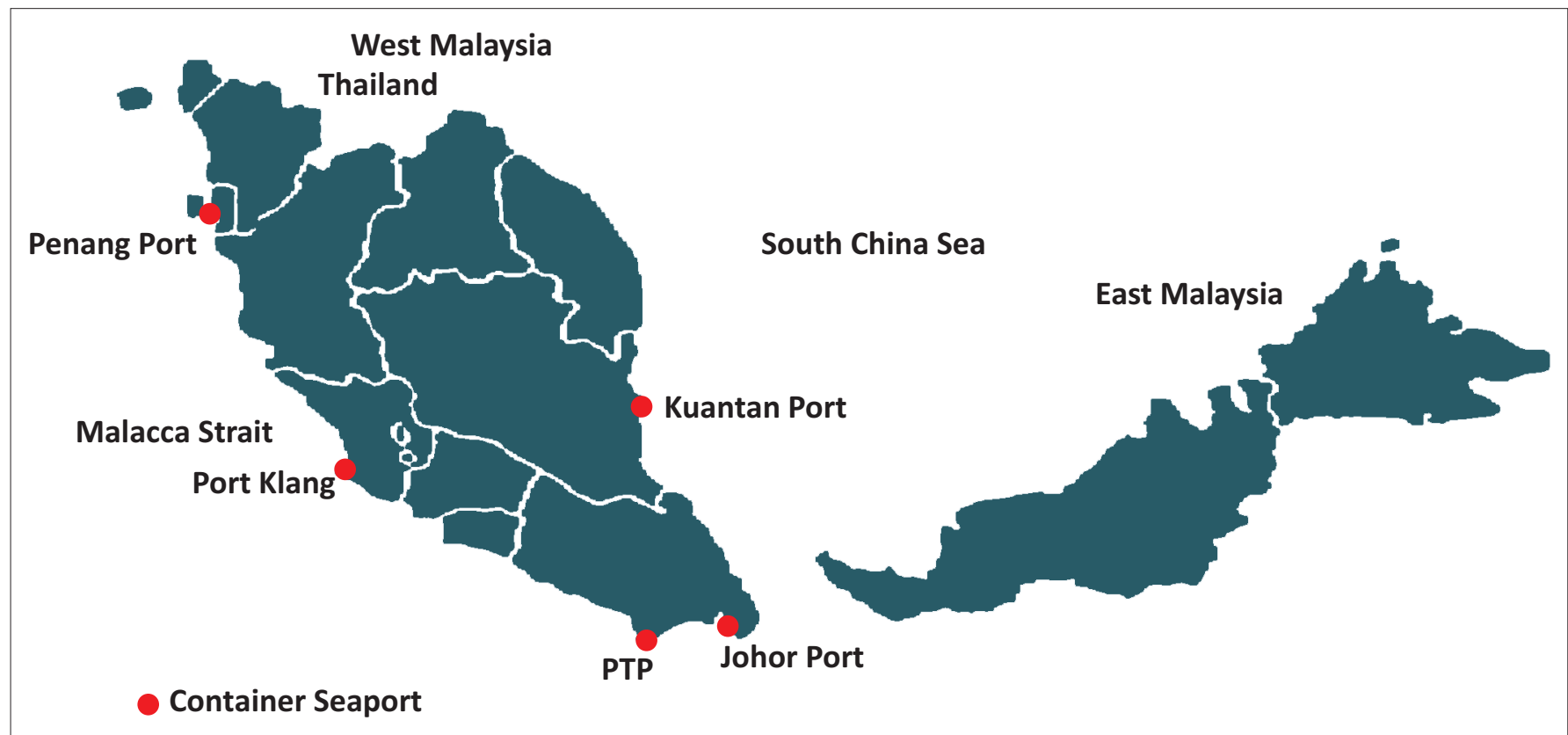

Source: Chen, S.L., Jeevan, J. \& Cahoon, S., 2016, 'Malaysian container seaport-Hinterland connectivity: Status, challenges and strategies', The Asian Journal of Shipping and Logistics 32(3), 127-138. https://doi.org/10.1016/j.ajsl.2016.09.001

PTP, Port of Tanjung Pelepas.

FIGURE 1: Location of five major contributing seaports in Malaysia. 
the Organization for Economic Cooperation and Development (OECD 2018), regional development is defined as a broad endeavour to minimise regional imbalance by supporting (jobcreating and wealth-generating) economic activity in regions. Regional development, according to Irina (2019), referred to actions that lead to the economic, social and cultural expansion of a certain region within a country. Bagia et al. (2019) and Yu et al. (2019) mentioned that regional development is concerned with economic and social growth comprising high-quality infrastructure (both soft and physical), well-developed community services, volume diversification in output, lower unemployment, an increasing number of jobs, wealth and improved quality of life. Hence in this paper, the concept of regional development comprises economic benefits, socio-economic development and environmental sustainability.

Regional development strategies should be founded on a thorough evaluation of regional resources, capacities, competencies and dynamic capabilities (Jacobs \& Notteboom 2011). These tactics are designed to create resource combinations and, as a result, a regional competitive advantage (Harmaakorpi \& Pekkarinen 2003). Dawkins (2003) proposed the concept of regional development as the interaction between three different matters. The first issue is the long-term convergence or divergence of per capita incomes between areas. The second is the relevance of internal and external economies of scale to regional economic growth, and the third is the function of space in determining regional labour outcomes. As a result, in order to design an efficient regional development plan, the application of space, the scale of economic activity, and the variance of income within the region must be addressed.

Furthermore, Mellander and Florida (2021) found that integrating firms and talents is imperative for driving innovation and growth. As a result, the combination of the seaport system as a business and human component dispersed throughout the region may result in major changes in the regional development environment. Lagendijk and Cornford (2000) presented a new paradigm of regional development to provide a different perspective. They proposed that new ideas of regional development should place a greater emphasis on innovation, competitiveness and the formation of specific configurations of regional institutions. This innovation, according to the authors, involve a new regional development model that emphasises variation and individuality. According to Haezendonck and Langenus (2019), the idea of competitiveness is the most important metric for assessing success. As a result, this idea may be used to evaluate regional growth by including the competitiveness component generated from the seaport system.

Over the last two decades, there has been a surge in studies on regional economic organisation. According to the literature, there is a clear trend toward a knowledge-driven economy. An area with the potential to support learning and innovation processes, in particular, and has a competitive edge in development processes (MacKinnon, Cumbers \& Chapman 2002). Thus, it can be concluded that regional competitive advantages play an important role in regional development and economic progress. Regional development, as defined in earlier research, is the process of balancing regional unevenness by enhancing a region's economic and social well-being using rapid methods to attain the ultimate objective of regional competitive advantages.

In practice, regional development has several goals, depending on the objectives of each of the development organisations. According to Ye et al. (2019), regional development occurs when two or more cities cross administrative boundaries to allow labour, capital, resources, technology and other factors to flow freely and form complementary advantageous regional competitiveness, in order to achieve common regional development. Ess and Lovanto (2008) in their study posited that development organisations must establish their goals based on the availability of resources and the needs of their respective current regions.

When it comes to regional development, seaports employ a variety of techniques (Sakalayen, Chen \& Cahoon 2016). Those techniques include association to create supply chain efficiency, collaboration with regional organisations for regional growth, proactive role in the regional innovation system and port's environmental and social responsibility. Seaport strategies such as regional seaports can network with industries, markets and production (Chen et al. 2016), which indirectly contributes to regional development (Sakalayen, Chen \& Cahoon 2017). Further, a regional innovation platform involving regional seaports will amplify the efficiency of seaport infrastructure (Infrastructure Australia 2010), which eventually boosts regional development.

The development of seaports is expected to boost the development in the region. Being the trigger source of economic activities and tourist development (Merk \& Comtois 2012; Musso, Ferrari \& Bennachio 2006; Jung 2011), seaports also contribute to economic growth and employment opportunity (Jung 2011; Omiunu 1989). For example, they can provide access to selected areas that previously do not have well-equipped infrastructures. They can benefit the economy by boosting the volume of shipping generated in a given region. Increased production volume should attract additional investment to the region, which, depending on government policy, should increase the number of available jobs and lower the area's overall unemployment rate (Sakalayen et al. 2016, 2017).

Moreover, it was found that the growth of a seaport and a region are both synchronised and complementary (Sakalayen et al. 2017). In the same vein, seaports also play a significant role in the economic growth of a country by accelerating regional development (Jouili 2016). In contrast, the impact of regional development on seaport growth remains unclear, which led to the initiation of this study. Essentially, the establishment of seaports to spur regional development is critical, since this node has a significant impact on national economic growth from a broader perspective. However, 
unavailability of inland freight facilities and limited multimodal transport network are some of the reasons for ineffective synchronisations between seaports, which lead to imbalanced regional development (Naidu 2008). From a microscopic view, this paper utilises seaports to evaluate their capacity to boost regional economic development from different perspectives. Although seaport is not a single entity that determines regional economic development, this paper's special attention to seaport as a substantial contributor is based on the literature review.

\section{Methodological approach}

The exploratory factor analysis (EFA) is implemented to explore the concept of regional development on the east coast by focusing on the seaport system. The list-based stratified sampling technique gathers sufficient data for the multiple sub-populations' analysis (Corlay \& Pages 2015). Studying a particular population's characters, viewpoints or stands on specific issues using this technique was proved to be effective (Creswell 2008). This sampling design allows better control over the samples and curbs fabricated identity, typical in Internet-based surveys (Simsek \& Veiga 2001). Furthermore, it enables the tracking of respondents' availability, and it is far more accurate and generates more representatives in each stratum than simple random sampling (Bethlehem \& Biffignandi 2012).

The EFA methodology is exploratory in nature, investigating the key aspects in order to develop a concept, hypothesis, or model from a vast number of respondents (Williams, Onsman \& Brown 2010). In this study, EFA was used to validate and investigate the relationship between the factors that explore the main factors in seaport systems that influence regional development in the east coast region, examines the implications of seaport systems on regional development and vice versa and proposes development strategies for the growth of seaports in this specific region. The nature of this research is focusing on exploratory design and an application of EFA is suitable to validate the themes that emerge from a constant comparison phase (Creswell \& Clark 2007).

The respondents chosen for the EFA were the Malaysian seaports' key stakeholders. The sampling population is divided into seven strata comprising hauliers, freight forwarders, rail operators, shippers, shipping lines and seaport operators as well as seaport authority. Based on their experience and expertise in seaport operations and the concept of regional development, the top-level and middlelevel managers (from the subpopulations mentioned above) who were involved in managing intermodal terminals, freight distribution and related logistics operations were invited to participate in the survey.

The survey questions have been divided into four sections. Section A focusses on the demographic profile of the participants. The remaining sections explore the main research questions proposed in this paper consisting of the impact of a seaport on regional development (Section B), the effect of regional development on the seaport sector (Section C), and lastly, the strategy to improve seaport development in east coast Malaysia (Section D).

\section{Result and discussion}

In between April and September 2020, about 260 questionnaires were distributed to Malaysian seaports and their respective stakeholders. A total of 120 responses were received, achieving a response rate of $46.2 \%$. This response rate is more than $33 \%$, which is the minimum indicator for the acceptance rate for an online survey (Nulty 2008). A total of $51(42.5 \%)$ responses were received from the freight forwarders, $11(9.2 \%)$ from the hauliers and 14 (11.7\%) from the shipping lines. Moreover, $20(16.7 \%)$ responses were received from the shippers, $8(6.7 \%)$ from the rail operators and $16(13.3 \%)$ from the seaports. Based on the response rate, shippers had the highest response rate of $100 \%$, whilst haulers had the lowest of $18.3 \%$.

\section{Demographic profile of the respondents}

Based on Table 1, it was found that $98.3 \%$ of the participants are from middle and top managerial levels, indicating that most of the participants have adequate experience, and this enables them to contribute significantly to this study. Further, according to DuBrin (2003), top- and middle-level managers possess a decisional role that ensures their organisations to plan development strategies and utilise resources. Therefore, the responses from this particular group provide substantial implications for this research. From the perspective of experience, $90 \%$ of the respondents possess valuable experience of more than 10 years, which provides another justification for the validity of the data in the section.

\section{Data suitability for exploratory factor analysis procedure through common method bias}

Before performing EFA, the suitability of data needs to be validated. Also, several steps need to be executed before performing the EFA. Firstly, the sample size needs to be more than 100 for producing significant results (Hair et al. 2010). As the sample size for this research is 111, it suits the factor analysis to produce substantial outcomes, especially in

\begin{tabular}{llcc}
\multicolumn{4}{l}{ TABLE 1a: } \\
\hline No. & Position & Response & Percentage \\
\hline 1 & Directors & 36 & 30 \\
2 & Coordinators & 2 & 1.7 \\
3 & Executives & 28 & 23.3 \\
4 & Manager & 51 & 42.5 \\
5 & Advisors & 3 & 2.5 \\
\hline
\end{tabular}

\begin{tabular}{llcc}
\multicolumn{5}{l}{ TABLE 1b: Demographic profile of respondents (Section A). } \\
\hline No. & Experience (in years) & Response & Percentage \\
\hline 1. & $0-5$ & 12 & 10 \\
2. & $6-10$ & 42 & 35 \\
3. & $11-15$ & 27 & 22.5 \\
4. & Over 16 & 39 & 32.5 \\
\hline
\end{tabular}


seaport and regional development research. Secondly, Bartlett's test of sphericity should be significant with $p<0.05$ to reflect the adequacy of correlations amongst variables as a normal indicator for factor analysis (Pallant 2011).

In this research, the $p$-value for all three constructs is 0.000 , which is significant (Rovai, Jason \& Michael 2013). The third step is related to the Kaiser-Mayer-Olkin (KMO) index, which tests the data suitability for EFA. The value of the KMO index should be greater than 0.6 (Rovai et al. 2013). In this research, the KMO index for Section B, C and D is 0.921, 0.784 and 0.914 , respectively, and this indicates the suitability of data for the extraction of factors. Finally, for bias analysis, the common method bias $(\mathrm{CMB})$ is required to ensure that the findings through EFA are free from unfairness. The CMB conducted through Harman single factor analysis uses EFA where all 38 variables are loaded into a single factor in this research. In any analysis, the newly introduced common latent factor that explains more than $50 \%$ of the variance indicates the presence of bias in the result (Eichhorn 2014). In this research, the common method variance (CMV) value is $46.722 \%$, and this indicates the absence of bias in the findings (see Table 2).

\section{Impacts of seaports on regional development}

According to Comrey and Lee (1992), the variables that come with a value of loading of more than 0.5 could help researchers to detect and identify components and make an explicit conclusion. They stated that extraction loading could be interpreted as poor, fair, good, very good and excellent when the values of loading are $0.32,0.45,0.55,0.63$ and 0.71 , respectively. In this paper, the variables with loading values of more than 0.5 will be kept to make conclusive assumptions about the implication of seaport on regional development, the impact of regional development on seaports and the strategy to improve the seaport development on the east coast of peninsular Malaysia.

Whilst performing the rotation on the variables, it was found that seven components exist, and those variables with loading values of above 0.5 are kept for discussion. Referring to Table 3, it can be noted that two components reached a cumulative percentage variance of $66.384 \%$. To highlight, these two components had an eigenvalue of more than 1. Impact of seaports on regional development are divided into geo-economic development and social development. The Cronbach's alpha value for the geo- economics component is 0.922 and for social development is 0.907 (see Table 3). Both these values indicate a relatively high level of accuracy in the measurement procedure (Rudner 2001).

\section{Geo-economic development}

The first implication of seaports on regional development is related to geo-economic development. The geo-economic development component consists of seaport centric logistics $\left(\mathrm{B}_{6}, 0.840\right)$, transportation hub $\left(\mathrm{B}_{5}, 0.826\right)$, maritime gateway $\left(\mathrm{B}_{4^{\prime}}\right.$ 0.813), socioeconomic development $\left(\mathrm{B}_{2^{\prime}}\right.$ 0.736), production volume $\left(\mathrm{B}_{9}, 0.708\right)$, infrastructure development $\left(B_{1}, 0.698\right)$, infrastructure quality $\left(B_{7}, 0.664\right)$ and maritime tourism activity $\left(\mathrm{B}_{3}, 0.572\right)$. In the meantime, infrastructure, the standard of living around seaport, people development, increasing use of seaport, utilisation of gas and oil industry for supply, job opportunities, increasing hinterland development and increase in road-rail connectivity are the main findings under the infrastructure development component.

Seaport centric logistics recorded the high loading values in this construct. According to Mangan, Lalwani and Fynes (2008), the main advantage of seaport centric logistics is providing land and labour at the lowest cost, reducing congestion at seaports, reducing dwelling time and providing direct links for deliveries for the customers. This situation provides an integrated connection between all players in the

TABLE 3: Reliability test on the exploratory factor analysis results (Section B). $\begin{aligned} & \text { Outcome from Impacts of seaports on regional development } \\ & \text { EFA }\end{aligned}$
$\begin{aligned} & \text { No. of items and } \\ & \text { Cronbach's alpha }\end{aligned}$

\begin{tabular}{|c|c|c|c|}
\hline & & $n$ & $\%$ \\
\hline $\begin{array}{l}\text { Geo-economic } \\
\text { development }\end{array}$ & $\begin{array}{l}B_{6} . \text { Seaport centric logistics } \\
B_{5} \cdot \text { Transportation hub } \\
B_{4} \cdot \text { Maritime gateway } \\
B_{2} . \text { Socio-economic development } \\
B_{9} . \text { Production volume } \\
B_{1} \cdot \text { Infrastructure development } \\
B_{7} \text {. Infrastructure quality } \\
B_{3} . \text { Maritime tourism activity }\end{array}$ & 8 & 0.922 \\
\hline $\begin{array}{l}\text { Social } \\
\text { development }\end{array}$ & $\begin{array}{l}B_{12} \text {. Average wealth } \\
B_{13} \text {. Quality of life } \\
B_{8} \text {. Community services } \\
B_{20} \text {. Upgrading regional development planning } \\
\text { strategies and tools } \\
B_{18} \text {. Urban development competitiveness and } \\
\text { governance } \\
B_{10} . \text { Low unemployment rate } \\
B_{11} \text {. Growing numbers of jobs }\end{array}$ & 7 & 0.907 \\
\hline
\end{tabular}

EFA, exploratory factor analysis.

TABLE 2: The result of common method bias.

\begin{tabular}{|c|c|c|c|c|c|c|}
\hline \multicolumn{7}{|c|}{ Total variance explained } \\
\hline \multirow[t]{2}{*}{ Component } & \multicolumn{3}{|c|}{ Initial eigenvalues } & \multicolumn{3}{|c|}{ Extraction sums of squared loadings } \\
\hline & Total & Percentageof variance & Cumulative percentage & Total & Percentage of variance & Cumulative percentage \\
\hline 1. & 18.220 & 47.947 & 47.947 & 17.754 & $46.722 *$ & 46.722 \\
\hline 2. & 3.322 & 8.742 & 56.668 & - & - & - \\
\hline 3. & 1.726 & 4.541 & 61.229 & - & - & - \\
\hline 4. & 1.427 & 3.754 & 64.984 & - & - & - \\
\hline
\end{tabular}

Note: *, Common Method Bias (CMB) value: $46.722 \%$. 
seaport system. Plus, this coordination and integration also enhances the seaport operations and developing the concept of seaport centric logistics. This will act as a stepping stone for the development of logistics hub, enhancing import and export activities through maritime gateways, increasing productivity and infrastructure development. This activity generates a new component in maritime business, which relates to maritime tourism. Through the concept of seaport centric logistics, regionalisation can be achieved, and this may provide a new milestone for seaport tourism.

\section{Social development}

The second implication of seaports on regional development is related to social development, consisting of seven items, which include average wealth $\left(\mathrm{B}_{12}, 0.843\right)$, quality of life, $\left(\mathrm{B}_{13}\right.$, $0.783)$, community services $\left(B_{8^{\prime}}, 0.741\right)$, upgrading regional development planning strategies and tools $\left(\mathrm{B}_{20^{\prime}} 0.730\right)$, urban development competitiveness and governance $\left(\mathrm{B}_{18}, 0.717\right)$, low unemployment rate $\left(\mathrm{B}_{10}, 0.678\right)$ and growing numbers of jobs $\left(\mathrm{B}_{11}, 0.622\right)$. The west coast of peninsular Malaysia is sufficient with well developed industrial zones, higher GDP, an active big scale manufacturing sector and the availability of logistic services for import and export. The state government on the east coast is not active in developing the maritime sector and thus has limited accessibility to foreign investment. According to the respondents of the survey, seaports can provide significant social-economic development. However, this can only be effective in the east coast region once the attractiveness of maritime sectors, inadequate regional development policy, and geopolitical factors are improved. The attractiveness of the maritime sector in this region always becomes an issue because of the monsoon season that falls between November until March every year. These are some of the major reasons why most of the trading vessels from East Asia are reluctant to utilise these facilities, especially in this region, and prefer to navigate the west coast of peninsular Malaysia for a contented trading ambience (Jeevan, Mohd \& Rosni 2018).

\section{Impact of regional development on seaports' growth}

The KMO index value is 0.784 , which is above the recommended value of 0.6 . Hence, the sampling adequacy is achieved for the data in Section C. Moreover, Bartlett's test of sphericity indicates the data is statistically significant $(p<0.05)$, confirming the correlation of variables towards factor analysis is reasonable (see Table 4).

The outcomes from the EFA consisted of two main impacts of regional development on seaports: seaport dynamic and maritime logistics hub, considering them as the major impact of regional development on seaports. The Cronbach's alpha value for seaport dynamic and maritime logistics hub components is 0.839 and 0.944 , respectively (see Table 5). In

TABLE 4: Kaiser-Meyer-Olkin and Bartlett's test (Section C).

\begin{tabular}{llc}
\hline Kaiser-Meyer-Olkin measure of sampling adequacy & $\mathbf{0 . 7 8 4}$ \\
\hline Bartlett's test of sphericity & Approximately chi-square & 312.163 \\
& Df & 15 \\
& Sig. & 0.000 \\
\hline
\end{tabular}

the meantime, there was a factor with only a single item and therefore could not be measured for Cronbach's alpha value. Christophersen and Konradt (2011) indicated that communality might be used as a conservative estimate of an item's reliability. Based on the communality value, the estimated reliability of the factor with a single item was 0.944 .

\section{Seaport dynamic}

The first implication of regional development on seaports is related to the seaport dynamic. This seaport dynamic consists of following items: infrastructure development $\left(C_{4^{\prime}}, 0.878\right)$, seaport centric logistics $\left(C_{3^{\prime}}\right.$ 0.865), socio-economic development $\left(C_{5}, 0.856\right)$, maritime getaway $\left(C_{1}, 0.815\right)$ and maritime tourism activity $\left(C_{6}, 0.512\right)$. These findings align with the outcome from the qualitative phase, emphasising on maritime gateway, seaport centric logistics and transportation hub. Besides providing impacts on the regional development, the seaports also might gain some implications because of the regional development in the region.

Once the region on the east coast has been developed, it might affect the infrastructure development, enhancement of seaport centric logistics and improvement in socio-economic development. In addition, the betterment of the functionalities of seaports as a maritime getaway and directing the new role of seaports as a centre of seaport maritime tourism activity, which will eventually contribute towards economic growth in the east coast of peninsular Malaysia. In that case, the enhancement of regional development may boost the dynamism of seaports to be more competitive and become pillars for the economic growth. According to Salleh et al. (2021), infrastructure development is crucial to support seaport activity, which becomes more crucial because of the enlargement of the vessel size from time to time. Most of the seaports in the west coast of peninsular Malaysia started to seek their assistance from inland, especially through inland ports, to support their competitive operation. Likewise, similar facilities and infrastructure need to be established in the east coast as preparation for seaports for more challenging trade activities in the future.

\section{Maritime logistics hub}

The second implication of regional development on seaports is related to maritime logistics hub, which consists of a single transportation hub $\left(C_{2}, 0.965\right)$. The easier and faster transportation of raw material to seaport affects the regional development supporting seaport activities via infrastructure facilities. In this case, seaports can be transformed into

TABLE 5: Reliability test on the exploratory factor analysis results (Section C). Outcome from Impact of regional development No. of items and Cronbach's EFA

\begin{tabular}{llcc}
\cline { 3 - 4 } Seaport & & $\boldsymbol{n}$ & $\mathbf{\%}$ \\
\hline & $C_{4}$. Infrastructure development & 5 & 0.839 \\
& $C_{3}$. Seaport centric logistics & & \\
& $C_{5}$. Socio-economic development & & \\
& $C_{1}$. Maritime getaway & & \\
& $C_{6}$. Maritime tourism activity & & 0.944 \\
Maritime & $C_{2}$. Transportation hub & 1 & \\
\hline
\end{tabular}


maritime logistics hubs to boost domestic economic growth activities, supply and demand chain and increase seaports' competitiveness from the land side. According to Wang et al. (2021), the transformation from ordinary seaport towards a maritime logistics hub is essential to ensure the sustainability of this entity and benefit the local economy, facilitate human capital transformation and to become a medium for environmental protection.

\section{The strategy of seaports development to boost regional development}

The KMO index for Section D is 0.914 (more than 0.6). The data support the required sampling adequacy for the study. Bartlett's test of sphericity is statistically significant $(p<0.05)$ and shows that the variables are correlated and suitable for factor analysis (see Table 6).

All these components were labelled subsequently as maritime sustainable strategy, seaport integration strategy and administrative strategy as the strategies for seaport development on the east coast of peninsular Malaysia. The Cronbach's alpha value for maritime sustainable strategy, seaport integration strategy and administrative strategy is 0.958, 0.789 and 0.985, respectively (see Table 7).

\section{Maritime sustainable strategy}

The first strategy to enhance seaport development is related to a maritime sustainable strategy. This maritime sustainable

\begin{tabular}{llc}
\multicolumn{3}{l}{ TABLE 6: Kaiser-Meyer-Olkin and Bartlett's test (Section D). } \\
\hline Kaiser-Meyer-Olkin measure of sampling adequacy & $\mathbf{0 . 9 1 4}$ \\
\hline Bartlett's test of sphericity & Approximately chi-square & 1048.422 \\
& Df & 66 \\
& Sig. & 0.000 \\
\hline
\end{tabular}

TABLE 7: Reliability test on the exploratory factor analysis results (Section D). Outcome from EFA Strategy for seaports development No. of items and

\begin{tabular}{|c|c|c|c|}
\hline & & \multicolumn{2}{|c|}{ Cronbach alpha } \\
\hline & & $n$ & $\%$ \\
\hline \multirow[t]{8}{*}{$\begin{array}{l}\text { Maritime sustainable } \\
\text { strategy }\end{array}$} & $\begin{array}{l}D_{9} . \text { Developing macroeconomic view of } \\
\text { regional development }\end{array}$ & 8 & 0.958 \\
\hline & $\begin{array}{l}D_{12} \text {. Assessment of urban development } \\
\text { competitiveness and governance; } \\
\text { analysis of existing regional institutions } \\
\text { and future prospects }\end{array}$ & & \\
\hline & $\begin{array}{l}D_{8} \text {. The strategy should be embedded in } \\
\text { its organisational, economic and social } \\
\text { context }\end{array}$ & & \\
\hline & $\begin{array}{l}D_{6} . \text { Prepare phases and sequences of } \\
\text { key investments and actions }\end{array}$ & & \\
\hline & $\begin{array}{l}D_{11} \text {. Assessment and reformulation of } \\
\text { regional industrial development strategy }\end{array}$ & & \\
\hline & $\begin{array}{l}D_{10} \text {. Critical assessment of land } \\
\text { development and management policy }\end{array}$ & & \\
\hline & $\begin{array}{l}D_{c_{1}} \text { Identifies clear mechanisms for } \\
\text { information delivery }\end{array}$ & & \\
\hline & $\begin{array}{l}D_{3} \text {. Establishes a widely shared vision for } \\
\text { the future development of the region }\end{array}$ & & \\
\hline $\begin{array}{l}\text { Seaport integration } \\
\text { strategy }\end{array}$ & $\begin{array}{l}D_{1} . \text { Boosting regional investment plan } \\
D_{2} \text {. Seaport and industrial park } \\
\text { development } \\
D_{4} \text {. Engages stakeholders in an open and } \\
\text { productive manner during the } \\
\text { preparation of the strategy }\end{array}$ & 3 & 0.789 \\
\hline $\begin{array}{l}\text { Administrative } \\
\text { strategy }\end{array}$ & $\begin{array}{l}D_{\text {. }} \text {. Establishes a simple but effective } \\
\text { framework for monitoring }\end{array}$ & 1 & 0.985 \\
\hline
\end{tabular}

EFA, exploratory factor analysis. strategy comprises developing macroeconomic view of regional development $\left(D_{9}, 0.887\right)$, assessment of urban development competitiveness and governance; analysis of existing regional institutions and prospects $\left(D_{12}, 0.879\right)$, strategy should be embedded in its organisational, economic and social context $\left(D_{8^{\prime}}\right.$ 0.879), prepare phases and sequences of key investments and actions $\left(D_{6}, 0.872\right)$, assessment and reformulation of regional industrial development strategy $\left(D_{11}, 0.871\right)$, critical assessment of land development and management policy $\left(D_{10^{\prime}}\right.$ 0.829), identifies clear mechanisms for information delivery $\left(D_{5}, 0.820\right)$ and establishes a widely shared vision for the future development of the region $\left(D_{3^{\prime}}, 0.799\right)$.

The limited attractiveness of maritime sectors in this region, especially because of limited efficiency and effectiveness of maritime sectors and limited competitiveness in seaports, connectivity and freight market, is the main challenges faced by seaports to enhance the regional development. In addition, some other challenges such as insufficient land for development near the port, issues in global trade, lack of shipping connectivity, less implementation of advanced technologies, less market demand and lack of infrastructure connecting to the east coast further delays the regional development in the east coast of peninsular Malaysia.

Therefore, a maritime sustainable strategy is required to overcome these issues. In this strategy, a macroeconomic view integrating political, economic, social, environmental and technological factors is required to boost the regional development in this part of Malaysia. Moreover, assessment of urban development competitiveness and governance, analysis of existing regional institutions and prospects especially through investment plan is highly required. In this case, the competitiveness of the seaport can be enhanced to attract more clients from the East Asian region as well as overcoming the poor attractiveness of maritime sectors in this region, which the east coast peninsular Malaysia is facing presently.

\section{Seaport integration strategy}

The second strategy to enhance seaport development is related to the seaport integration strategy. The seaport integration strategy consists of the items: boosting regional investment plan $\left(D_{1}, 0.834\right)$, seaport and industrial park development $\left(D_{2}, 0.819\right)$ and engages stakeholders openly and productively during the preparation of the strategy $\left(D_{4^{\prime}}\right.$ 0.776). The industrial park development might enhance the regional development in this region. This is crucial to attract investors, upgrade infrastructure, use industrial park developers to develop the industrial park with value-added services and strategic government's fiscal policy to create industrial zone and development. With this strategy, the seaport, especially on the east coast, may engage with stakeholders to collectively cooperate to enhance the regional development through seaport activities. With this the issues related to inadequate regional development policy, geographical and geopolitical factors can be resolved. 


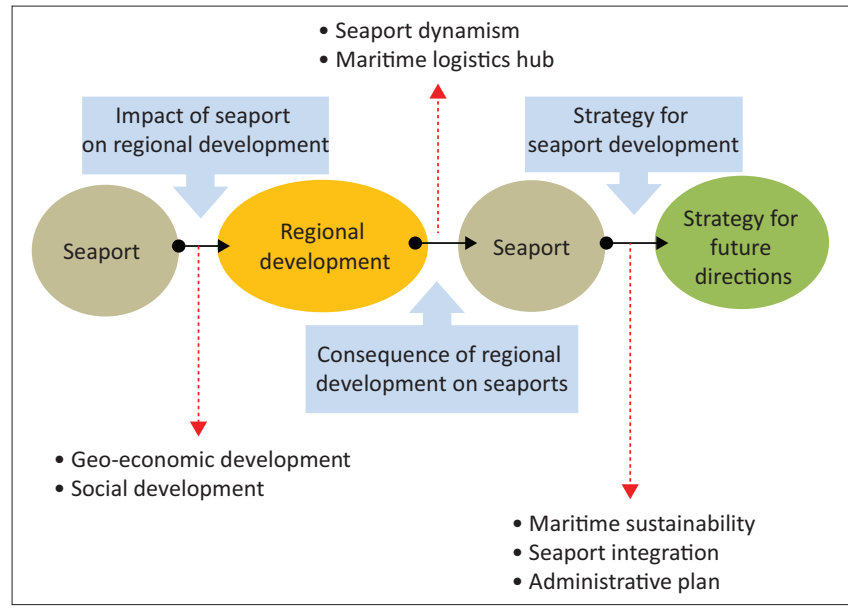

FIGURE 2: Summary of the findings.

\section{Administrative strategy}

The third strategy to enhance seaport development is related to administrative strategy. The administrative strategy consists of a single item, namely establish a simple but effective framework for monitoring $\left(D_{7}, 0.985\right)$. Seaports in east coast Malaysia own some advantages such as the prospect of infrastructure development, availability of maritime industrial park and maritime service diversification. Therefore, a clear inland port policy is required to integrate seaport and inland components as a simple but effective framework for monitoring both of these entities. The introduction of inland port policy is required to simplify the critical functionalities of seaports, especially in the east coast region. However, solid inland ports are not available on the east coast, and currently, they are employing some inland terminals on the west coast, which affects the efficiency of seaport performance.

Figure 2 visualises the summary of the findings in this paper. The figure clearly indicates that the connection between seaport and regional development in east coast Malaysia is complementary, because of the reciprocal implications and consequences gained by seaports before and after the amalgamation of the concept of regional development in this key trade node. In the meantime, the assessment of seaports and regional development need to be carried out continuously as a result of the rapid vicissitudes in the maritime sector. Hence, this consistency will guarantee the healthy symbiotic relationship between seaports and their respective community in the east coast region of peninsular Malaysia.

\section{Conclusion and implication}

The EFA results show two main impacts of seaports on regional development: geo-economic development and social development. The geo-economic development component consists of seaport-centric logistics, transportation hub, maritime gateway, socio-economic development, production volume, infrastructure development, infrastructure quality and maritime tourism activity. Seaports have a significant potential to enhance regional development on the east coast by improving social development, average wealth, quality of life, community services, upgrading regional development planning strategies and tools, urban development competitiveness and governance, unemployment rate and increasing numbers of jobs. In contrast, the impact of regional development on seaport growth also has been analysed. Furthermore, the findings also indicate that the regional development in east coast Malaysia will provide a high possibility for transportation hub development especially for bulk and non-bulk cargo via ocean and land economic activities.

To boost seaport growth in the east coast of peninsular Malaysia, three strategies have been proposed: maritime sustainable strategy, seaport integration strategy and administrative strategy. For maritime sustainable strategy, several variables need to be considered, such as developing macroeconomic view of regional development, assessing urban development competitiveness and governance and analysing existing regional institutions and others for the future development of the region. Secondly, an integration strategy also has been recommended to boost the seaport growth. This seaport integration strategy consists of boosting regional investment plan, seaport and industrial park development and engaging stakeholders openly and productively during the preparation of the strategy. Thirdly, establishing an effective framework for monitoring the symbiosis between seaports and regional development is required in the administrative strategy.

\section{Acknowledgements Competing interests}

The authors declare that they have no financial or personal relationships that may have inappropriately influenced them in writing this article.

\section{Authors' contributions}

R.S. contributed to the conceptualisation, methodology, data collection, data curation, format analyses and research writing. J.J., N.H.M.S. and M.R.O. were responsible for research writing, review and editing, validation and verification. K.M. and A.H.N. also contributed to the validation and verification of results. Both J.J. and N.H.M.S. approved the final manuscript.

\section{Ethical considerations}

This article followed all ethical standards for research without direct contact with human or animal subjects.

\section{Funding information}

This research was conducted under the Ministry of Higher Education Fundamental Research Grant Scheme (UMT/ 
RMIC/FRGS/1/2019/59603). Universiti Malaysia Terengganu provided the research facilities.

\section{Data availability}

Data that support the findings of this study will be provided upon reasonable request from the corresponding author, J.J.

\section{Disclaimer}

The views and opinions expressed in this paper are those of the authors and do not necessarily reflect the official policy of any affiliated agency of the authors.

\section{References}

Bagia, I.W., Cipta, W. \& Suarmanayasa, N., 2019, 'Job characteristics analysis and its influence on the performance at the employee's local government of Buleleng regency', in International Conference on Tourism, Economics, Accounting, Management, and Social Science (TEAMS 2018), Atlantis Press, pp. 32-37.

Bethlehem, J. \& Biffignandi, S., 2012, Handbook of web surveys, Wiley, Hoboken, NJ.

Chen, S.L., Jeevan, J. \& Cahoon, S., 2016, 'Malaysian container seaport-Hinterland connectivity: Status, challenges and strategies', The Asian Journal of Shipping and Logistics 32(3), 127-138. https://doi.org/10.1016/j.ajsl.2016.09.001

Christophersen, T. \& Konradt, U., 2011, 'Reliability, validity, and sensitivity of a single item measure of online store usability', International Journal of Human-Computer Studies 69(4), 269-280. https://doi.org/10.1016/j.ijhcs.2010.10.005

Comrey, A.L. \& Lee, H.B., 1992, Interpretation and application of factor analytic results, 2nd edn., Lawrence Erlbaum Associates, Mahwah, NJ.

Corlay, S. \& Pagès, G., 2015, 'Functional quantization-based stratified sampling methods', Monte Carlo Methods and Applications 21(1), 1-32. https://doi. org/10.1515/mcma-2014-0010

Creswell, J.W., 2008, Educational research: Planning, conducting and evaluating quantitative and qualitative research, 3rd edn., Kevin M. Davis, Merchantville, NJ.

Creswell, J.W. \& Clark, L.P., 2007, Designing and conducting mixed methods research, 1st edn., Sage, Thousand Oaks, CA.

Dawkins, C.J., 2003, 'Regional development theory: Conceptual foundations, classic works, and recent developments', Journal of Planning Literature 18(2), 131-172. https://doi.org/10.1177/0885412203254706

DuBrin, A.J., 2003, Essentials of management, 6th edn., Thomson South-Western, Peterborough.

Eichhorn, B.R., 2014, Common method variance techniques, Cleveland State University, Department of Operations and Supply Chain Management, SAS Institute Inc., Cleveland, $\mathrm{OH}$.

EPU, 2015, The logistics and trade facilitation masterplan, Economic Planning Unit, Kuala Lumpur.

Ess, M. \& Lovanto, B., 2008, Regional economic development: An analysis of practices, resources and outcomes, The Thomas Jefferson Program in Public Policy, The College of William and Mary, Williamsburg, VA.

Haezendonck, E. \& Langenus, M., 2019, 'Integrated ports clusters and competitive advantage in an extended resource pool for the Antwerp seaport', Maritime Policy \& Management 46(1), 74-91. https://doi.org/10.1080/03088839.2018.1471535

Hair, J.F., Black, W.C., Babin, B. \& Anderson, R.E., 2010, Multivariate data analysis: A global perspective, 7th edn., Pearson, London.

Harmaakorpi, V. \& Pekkarinen, S., 2003, The concept of the regional development platform and regional development platform method (RDPM) as a tool for regional development, European Regional Science Association (ERSA), Louvain-laNeuve, viewed 24 April 2021, from http://hdl.handle.net/10419/116150.

Infrastructure Australia, 2010, National ports strategy, viewed 05 October 2010, from https://www.infrastructureaustralia.gov.au/listing/media-release/2010infrastructure-australia-report-coag-getting-fundamentals-right-australiasinfrastructure-priorities.

Irina, M., 2019, 'Strategic competitive management of human resources on Moldovan labour market in the conditions of regional development', PhD thesis, Academy of Economic Studies of Moldova.

Jacobs, W. \& Notteboom, T., 2011, 'An evolutionary perspective on regional port systems: The role of windows of opportunity in shaping seaport competition', Environment and Planning A 43(7), 1674-1692. https://doi.org/10.1068/ a43417

Jeevan, J., Chen, S.L. \& Cahoon, S., 2019, 'The impact of dry port operations on container seaports competitiveness', Maritime Policy \& Management 46(1), 4-23. https://doi.org/10.1080/03088839.2018.1505054
Jeevan, J., Ghaderi, H., Bandara, Y.M., Saharuddin, A.H. \& Othman, M. R., 2015, 'The implications of the growth of port throughput on the port capacity: The case of Malaysian major container seaports', International Journal of e-Navigation and Maritime Economy 3, 84-98. https://doi.org/10.1016/j.enavi.2015.12.008

Jeevan, J., Harun, M., Abdullah, W.M.W., Othman, M.R., Salleh, N.H.M. \& Caesar, L.D., 2021a, 'The belt and road initiative: A pragmatic constituent for the growth of Malaysian seaport system', World Review of Intermodal Transportation Research 10(3), 225-244. https://doi.org/10.1504/WRITR.2021.117668

Jeevan, J., Mohd, S.N.H. \& Rosni, O.M., 2018, 'Thai Canal and Malacca straits: Complementing or competing stratagem for trade development in South East Asia', Journal of Sustainable Development of Transport and Logistics, 3(2), 34-48. Asia', Journal of Sustainable Development
https://doi.org/10.14254/jsdtl.2018.3-2.2

Jeevan, J., Othman, M.R., Salleh, N.H.M., Ghani, N.M.A., Noralam, N.A. \& Divine Caesar, L, 2020 'An analysis on the triadic connection between seaports, inland terminals and hinterland market', Australian Journal of Maritime and Ocean Affairs 13(1), 23-42. https://doi.org/10.1080/18366503.2020.1834063

Jeevan. J., Rahadi, R.A., Zaideen, I.M.M., Salleh, N.H.M. \& Othman, M.R., 2021b, 'Reconnoitering the contributions of dry ports on the regional development in Malaysia', Australian Journal of Maritime \& Ocean Affairs. https://doi.org/10.108 0/18366503.2021.1962058

Jeevan, J., Selvaduray, M., Salleh, N.H.M., Ngah, A.H. \& Zailani, S., 2021c, 'Evolution of industrial revolution 4.0 in seaport system: An interpretation from a bibliometric analysis', Australian Journal of Maritime \& Ocean Affairs. https://doi.org/10.1080 /18366503.2021.1962068

Jouili, T.A., 2016, 'The role of seaports in the process of economic growth', Developing Country Studies 6, 64-69.

Jung, B.M., 2011, 'Economic contribution of ports to the local economies in Korea', The Asian Journal of Shipping and Logistics 27(1), 1-30. https://doi.org/10.1016/ S2092-5212(11)80001-5

Lagendijk, A. \& Cornford, J., 2000, 'Regional institutions and knowledge-tracking new forms of regional development policy', Geoforum 31(2), 209-218. https://doi. org/10.1016/S0016-7185(99)00031-7

Latip, A.R.A. \& Yusoff, O.M., 2019, 'Regional development in Malaysia: A socioeconomic impacts of human capital development programs', in Economic and Social Development: Book of Proceedings, 47 th International Scientific Conference Social Development: Book of Proceedings, 47th International Scientific Conference
on Economic and Social Development, Prague, November 14-15, 2019, pp. 8-16.

MacKinnon, D., Cumbers, A. \& Chapman, K., 2002, 'Learning, innovation and regional development: A critical appraisal of recent debates', Progress in Human Geography 26(3), 293-311. https://doi.org/10.1191/0309132502ph371ra

Mangan, J., Lalwani, C. \& Fynes, B., 2008, 'Port-centric logistics', International Journal of Logistics Management 19(1), 29-41. https://doi.org/10.1108/0957409081 0872587

Mellander, C. \& Florida, R., 2021, 'The rise of skills: Human capital, the creative class, and regional development', in C. Mellander \& R. Florida (eds.), Handbook of regional science, pp. 707-719, The Royal Institute of Technology, Centre of Excellence for Science and Innovation Studies (CESIS), Stockholm.

Menhat, M.N.S., Zaideen, I.M.M., Yusuf, Y., Salleh, N.H.M., Zamri, M.A. \& Jeevan, J., 2021, 'The impact of covid-19 pandemic: A review on maritime sectors in Malaysia', Ocean \& Coastal Management 209, 105638. https://doi.org/10.1016/j. ocecoaman.2021.105638

Merk, O. \& Comtois, C., 2012, 'The competitiveness of global port-cities: The case of Marseille-Foss - France', OECD Regional Development Working Paper, No. 2012/11, OECD Publishing, Paris.

Musso, E., Ferrari, C. \& Bennachio, M., 2006, 'Port investment: Profitability, economic impact and financing', Research in Transportation Economics 16(1), 171-218. https://doi.org/10.1016/S0739-8859(06)16008-4

Naidu, G., 2008, 'Infrastructure development in Malaysia', in N. Kumar (ed.), International infrastructure development in East Asia-Towards balanced regional development and integration, ERIA Research Project, pp. 204-207, Institute of Developing Economies, Chiba.

Nulty, D.D., 2008, 'The adequacy of response rates to online and paper surveys: What can be done?', Assessment and Evaluation in Higher Education 33(3), 301-314. https://doi.org/10.1080/02602930701293231

OECD, 2018, Regional development policy, Organization for Economic Co-operation and Development, viewed 20 February 2019, from http://www.oecd.org/gov/ regional-policy/.

Omiunu, F.G.I., 1989, 'The port factor in the growth and decline of Warri and Sapele townships in the Western Delta Region of Nigeria', Applied Geography 9(1), 57-69. https://doi.org/10.1016/0143-6228(89)90005-2

Othman, M.R., Jeevan, J., Salleh, N.H. \& Noralam, N.A., 2020, Applying and promoting the seaport quality system (SQS) and spatial interaction model (SIM) for the sustainable development of the recreational seaport industry in Malaysia Tourism, IntechOpen, London.

Pallant, J., 2011, SPSS survival manual: A step by step guide to data analysis using SPSS, Allen and Unwin, Crows Nest.

Rovai, A.P., Jason, D.B. \& Michael, K.P., 2013, Social science research design and statistics: A practitioner's guide to research methods and IBM-SPSS, Watertree Press LLC, Chesapeake, VA.

Rudner, L.M., 2001, 'Informed test component weighting', Educational Measurement: Issues and Practice 20(1), 16-19. https://doi.org/10.1111/j.1745-3992.2001. tb00054.x

Sakalayen, Q.M., Chen, P.S.L. \& Cahoon, S., 2016, 'Investigating the strategies for Australian regional ports' involvement in regional development', International Journal of Shipping and Transport Logistics 8(2), 153-174. https://doi. org/10.1504/IJSTL.2016.075012 
Sakalayen, Q.M., Chen, P.S.L. \& Cahoon, S., 2017, 'The strategic role of ports in regional development: Conceptualising the experience from Australia', Maritime
Policy and Management 44(8), 933-955. https://doi.org/10.1080/03088839.201 Policy and

Salleh, N.H.M, Selvaduray, M., Jeevan, J., Ngah, A.H. \& Zailani, S., 2021a, 'Adaptation of industrial revolution 4.0 in a seaport system', Sustainability 13(19), 10667. https://doi.org/10.3390/su131910667

Salleh, N.H.M., Zulkifli, N. \& Jeevan, J., 2021b, 'The emergence of very large container vessel (VLCV) in maritime trade: Implications on the Malaysian seaport operations', WMU Journal of Maritime Affairs 20(1), 41-61. https://doi.org/10.1007/s13437020-00225-9

Simsek, Z. \& Veiga, J.F., 2001, 'A primer on internet organisational surveys', Organizational Research Method 4(3), 218-235. https://doi.org/10.1177/ 109442810143003
Wang, C., Haralambides, H. \& Zhang, L., 2021, 'Sustainable port development: the role of Chinese seaports in the 21st century Maritime Silk Road', International Journa of Shipping and Transport Logistics 13(1-2), 205-232.

Williams, B., Onsman, A. \& Brown, T., 2010, 'Australian paramedic graduate attributes: A pilot study using exploratory factor analysis', Emergency Medicine Journal 27(10), 794-799. https://doi.org/10.1136/emj.2010.091751

Ye, C., Zhu, J., Li, S., Yang, S. \& Chen, M., 2019, 'Assessment and analysis of regional economic collaborative development within an urban agglomeration: Yangtze River Delta as a case study', Habitat International 83, 20-29. https://doi. org/10.1016/j.habitatint.2018.10.010

Yu, Z., Yao, Y., Yang, G., Wang, X. \& Vejre, H., 2019, 'Strong contribution of rapid urbanization and urban agglomeration development to regional thermal environment dynamics and evolution', Forest Ecology and Management 446, 214-225. https://doi.org/10.1016/j.foreco.2019.05.046 